\title{
Giles Milton: Weißes Gold. Die außergewöhnliche Geschichte von Thomas Bellow und das Schicksal weißer Sklaven in Afrika
}

Konrad Theiss Verlag, Stuttgart, 2010

\author{
Jürgen G. Backhaus
}

Published online: 25 May 2014

(C) Springer Science+Business Media New York 2014

About a thousand people were enslaved in the early eighteenth century by a man who was intent on building a palace that would stretch $500 \mathrm{~km}$, a giant compared to Speer.

He sent ships out that would either capture other ships as close to England's shore as at the mouth of the canal or else got ashore and pick up villagers for enslavement.

Little is known about this long ruling maniac, Mulai Ismail by name, who also treated his white slaves with unusual cruelty. The 2,000 concubines he had must clearly have surpassed his appetite, and the sumptuous palace was filled with intrigue and cruelty. No wonder that eunuchs would let off their anger and desperation in acts of cruelty.

The carriage in which the ruler was brought into his palace was drawn by people!

This is a rarely told aspect of slavery. While the American South practiced slavery which would ultimately end in freedom, this ruler used sheer brute force to enforce the relationship.

While in the American North, people had arrived who, in order to escape servitude, had sold 20 years of their working ability and then could expect a small farm, the South had practiced outright slavery from birth, which, likewise, would normally end in freedom and also, typically, a small estate!

These desperate seamen could not expect such treatment. The few who escaped did not yet return to a homeland with a welfare hammock to rest, but with their experiences ready to be told; they were published commercially by specialized agents.

As their tales were an embarrassment to the governments that had not come to their help, the tales were often doubted. Milton shows that they were indeed credible to the minute detail.

This is indeed required reading for any course in Afro-American studies.

J. G. Backhaus $(\bowtie)$

Krupp Chair in Public Finance and Fiscal Sociology, University of Erfurt, Nordhäuser Strasse 63, 99089 Erfurt, Germany

e-mail: juergen.backhaus@uni-erfurt.de 